Agnieszka Stępińska, Ewa Jurga-WosiK, Kinga Adamczewska, Bartłomiej Secler, Dominika Narożna Adam Mickiewicz University in Poznań, Poland

\title{
Journalistic role performance in Poland
}

\begin{abstract}
Several research projects in the last decade have been devoted to studying professional role perception among Polish journalists. Still less is known about how different ideals of professional roles affect journalistic role performance. This paper aims to present the findings of the content analysis of 1,130 news stories published in four Polish newspapers in 2012 and 2013. The study was a part of the international research project: Journalistic Role Performance Around the Globe (led by Prof. Claudia Mellado from Pontificia Universidad Católica de Valparaíso, in Chile and Lea Hellmueller, from Texas States University, www.journalisticperformance.org). The results indicate that the watchdog model is most commonly used in the Polish press, followed by the infotainment and civic models. However, the findings of the content analysis primarily support the general observation on the political orientations of the Polish newspapers and political parallelism of the Polish media system.
\end{abstract}

Key words: journalism, Poland, professional roles, professional performance

\section{Introduction}

$\mathbf{I}$

$\mathrm{n}$ the past couple years several research projects were devoted to studying professional role perception among Polish journalists (Stępińska, Ossowski, Pokrzycka, Nowak, 2012; Głowacki, 2013; Dobek-Ostrowska, Barczyszyn, Michel, 2013). Although these studies have strongly contributed to the analysis of the normative and empirical models of Polish journalism, still little is known about how different ideals of professional roles affect journalistic role performance. While the professional conception was studied with surveys conducted among media people, the examination of the latter requires conducting studies on journalistic discourses and writing styles as the outcomes of newsroom and individual journalists' decisions. This paper presents the findings of a content analysis of news items published by Polish journalists working for selected daily newspapers. The study is a part of the ongoing international research project: Journalistic Role Performance Around the Globe. 


\section{Theoretical background}

Journalists' role conception can be defined as the generalized expectations which journalists believe exist in society and among different stakeholders which they see as normatively acceptable, and which influence their behaviour on the job. Journalists' role conceptions have been studied primarily for news workers involved in covering politics and current affairs. It is assumed that the way journalists understand their role will strongly influence the way they interact with news sources and make decisions about news selection and presentation (Donsbach, 2008).

Theoretical considerations and empirical studies on journalistic performance resulted in recognizing several distinctions of journalists' attitudes. Culbertson (1983) distinguished three main attitudes among US journalists: (1) traditional (neutral), stressing fact accuracy and speed; (2) interpretative, incorporating social science and historical research to study every aspect of the events and their meanings; (3) activists, or proactive reporting with a list of prescriptions to correct the illness of society. A decade later, Weaver and Wilhoit (1996) made a distinction of four main media roles, that is (1) a disseminator (getting information to the public quickly and avoiding stories with unverifiable information), (2) interpretative/investigative (investigating government claims, analyzing and interpreting issues and discussing public policy while it is being developed), (3) adversarial (being constantly skeptical of government and businesses), and (4) a populist mobilizer (developing the cultural interests of the public, providing entertainment, setting the political agenda and giving ordinary citizens a chance to express their views).

Although that typology was developed based on the US experience, it served as a theoretical background for studies of journalists in many other countries (including Poland) conducted under two international projects: "The Global Journalist" and "The Global Journalist in the $21^{\text {st }}$ Century" (Weaver, 1998; Olędzki, 1998; Weaver, Willnat, 2012; Stępińska, Ossowski, Pokrzycka, Nowak, 2012).

More recently, a concept of journalistic cultures has been developed by Hanitzsch (2007). Journalistic culture emphasizes not only values, attitudes and beliefs (perception or conception), as the previous concepts did, but also practices and artifacts (performance). Hanitzsch (2007) defines three constituents of journalistic culture: institutional roles, epistemologies, and ethical ideologies, as well as three basic dimensions of the journalists' role performance: (1) interventionism, (2) power distance, and 
(3) market orientation. As a result, he distinguishes four main models of journalism: (1) a detached watchdog (interested in providing the audience with political information, high distance towards power political elites, skeptical and critical attitude); (2) populist disseminator (strong orientation towards the audience, focus on providing the audience with 'interesting' information, low level of interventionism); (3) critical change agent (driven by interventionist intentions, critical towards government and business elites, emphasis on advocating social change, influencing public opinion or setting the political agenda); and (4) opportunist facilitator (constructive partners of the government, support for official policies, close distance to political powers).

Alongside that concept, Mellado (2014) suggests a concrete operationalization of six dimensions of journalistic role performance that emerge from three different domains that have been discussed by previous literature: (a) the relationship journalism has with those in power, (b) the presence of the journalistic voice in a story, and (c) the way journalism approaches the audience. Each one of these six dimensions is characterized by different measures of professional practice. The disseminatorinterventionist dimension deals with the active-passive stance of the journalists in their reporting (Donsbach, Patterson, 2004; Weaver, Wilhoit, 1996). While the disseminator role is here characterized by neutrality and distance between the journalist and the facts, an interventionist role is defined as more journalist-centered, where the news professionals provide their own opinions, suggestions and they sometimes argue for different groups in society.

Two dimensions of role performance are identified regarding the domain of power relations: the watchdog and the loyal-facilitator. While the former is focused on questioning, criticism, or accusations against those in power, the latter materializes in two facets. In its first variant, journalism cooperates with those in power, and protects the status quo by supporting institutional activities carried out by the political or economic elite, promotes national or regional policies, and gives a positive image of the political and economic elite. In the second, the focus is on the nation-state unit, encouraging the sense of belonging to one's country and strengthening national prestige.

Finally, based on different understandings of the audience, Mellado (2014; see also: Mellado, Lagos, 2014) identified three independent dimensions of role performance and three approaches toward the audience: service (audience as clients), infotainment (spectators), and civic-ori- 
ented journalism (citizens). Service journalism combines the rights and self-interests of the audience, creating a client-professional relationship between the journalist and the public. As an answer to the growing complexity of modernity, this model of role performance provides help, tips, guidance and information about the management of day-to-day life and individual problems.

Infotainment journalism (also called tabloid journalism) addresses the public as spectators and provides news stories with elements of personalization, private life, scandal, sensationalism, emotions, and morbid curiosity. The infotainment model of journalism uses different stylistics, narrative and/or visual discourses in order to entertain and thrill the public (such as exaggeration, emphasis of the incredible, the use of dramatic superlative adjectives and metaphors that highlight the unusual, spectacular or unexpected). In practice, the news items center on one or more persons and their different intellectual, physical, mental or social characteristics (i.e. competence, leadership, appearance, capacity) or personal background (where they worked, studied, their name, marital status, etc.), or focus on the private life of one or more individuals. Journalists may also focus on an event or incident framed as a scandal, such as an illegitimate or immoral event that does not have to do with actions associated to a public role, although in general the protagonist is a well-known individual (Mellado, 2014).

Civic-oriented journalism is concerned with educating the common citizen about complex and controversial topics, encouraging people to get involved in public debate and to participate in political events. The dominating perspective in the news item is the presentation of groups without social empowerment that demand the recognition or restoration of a right. Other characteristics of this model of journalism include developing the audience's cultural and intellectual interest. This model does not assume that it is the journalists who can create an improved community via their own resources; rather the emphasis is on supporting the citizens' effort to do so. In this sense, the journalistic work closest to this role allows people to do their jobs as citizens.

The civic model of journalism incorporates some aspects of social responsibility theory, focusing on the connection/between journalism, the citizenry and public life. Journalistic performance that adopts these ideas is concerned with encouraging the public to get involved in public debate, and to participate in social, political and cultural life. In this sense, the space given to sources and actors not always considered by the media is 
an important aspect for this model. This model also resonates with one of the several definitions of development journalism, where journalism can raise awareness of profound problems, helping to inform government agents about social needs (Mellado, 2014).

In this paper we will present the data on the presence of indicators of the models related to two domains: (1) the relation between media and political actors and (2) the relation between media and society (citizens).

\section{The empirical analysis}

\section{Sampling}

The study has been conducted on a sample of the content of four daily newspapers. The choice of media organizations was based on: (1) the type of media organization (quality newspapers and tabloids), (2) circulation and (3) political orientation. We selected the following media organizations:

a) Gazeta Wyborcza - a nationwide, somewhat liberal news daily, focused mostly on political current affairs, owned by the Agora S.A. media concern. Gazeta Wyborcza is among the leaders of the daily press in Poland. Since its origin in 1989, Adam Michnik has been its editor-in-chief. According to the 2014 data, average circulation amounts to 278,000 issues with sales at a level of 209,000 issues (Wirtualne Media, 2014).

b) Rzeczpospolita - a nationwide news daily with a socio-political, economic and legal profile. It defines itself as "the only conservative-liberal journal in Poland." The daily has enjoyed a strong market position for many years. It is among the leaders of dailies in Poland, although it has recently noted a sales drop. Average circulation exceeds 69,000 issues with sales oscillating around 59,000 issues sold on average (Wirtualne Media, 2014).

c) Nasz Dziennik - a nationwide Catholic-nationalistic daily published by the Spes sp. z o.o. - a limited liability company. The daily was initiated in January 1998 by Rev. Tadeusz Rydzyk, the founder of the ultraCatholic Radio Maryja. The newspaper's circulation is not monitored by the Association for Control of Press Distribution (ZKDP) which accounts for the lack of precise statistics as to sales. The information provided by the editor, however, indicates that average circulation is at a level of 150,000 issues with sales of 100,000 issues. 
d) Fakt - a nationwide daily tabloid, published since 2003 by Axel Springer Polska, a part of the Axel Springer AG media concern. Fakt is the leader among the daily press in Poland. Statistics from 2014 indicate that average circulation exceeded 474,000 issues with average sales of 352,000.

Using the constructed week method, a stratified-systematic sample of each newspaper was selected. Since none of the Polish newspapers has a Sunday edition, we followed the instruction provided by the leaders of the JRP project and chose the next day as a substitution for the selected day. In 2012 there were 2 such cases: January 22 (Sunday) - substituted with January 23 (Monday), and September 16 (Sunday) - substituted with September 17 (Monday). In 2013 there were two more such cases: February 3 (Sunday) - substituted with February 4 (Monday) and July 7 (Sunday) - substituted with July 8 (Monday). Moreover, one selected day - May 3 (Thursday) fell on a national holiday. Since there was no newspaper published on that day, we substituted it with May 4 (Friday).

All news stories published in sections associated to the national desk (including stories located in the front page) were coded. We made a distinction between news and editorials and excluded the latter. We also excluded interviews, single quotes, lone headlines and photographs with only a caption. The selection criteria affected the sample in the case of the tabloid newspaper Fakt, as well as the quality newspaper - Gazeta Wyborcza. More precisely, Fakt just introduces the materials on the first page (headlines or headlines with pictures), while Gazeta Wyborcza publishes promos on the first page, but most of them are just one-sentence or two-sentence abstracts of the main text published on another page. Since such promos neither provide any extra information (they include exactly the same sentences that are used in a regular text), or show any other journalistic attitude, we decided to exclude them, too. The total number of items is 1,130 . Table 1 shows more details on the sample.

Table 1

\section{Sample}

\begin{tabular}{||l|c|c|}
\hline \multicolumn{1}{|c|}{ Newspaper } & Number of items & Percentage \\
\hline Gazeta Wyborcza & 342 & 30.3 \\
\hline Rzeczpospolita & 255 & 22.5 \\
\hline Fakt & 303 & 26.8 \\
\hline Nasz Dziennik & 230 & 20.3 \\
\hline TOTAL & $\mathbf{1 1 3 0}$ & $\mathbf{1 0 0 . 0}$ \\
\hline
\end{tabular}




\section{Findings}

Watchdog model

Table 2 presents the data on two indicators of the watchdog model: (1) questioning of individuals or groups of power through quotes, statements and/or opinions given by either journalists or others, (e.g. actors presenting information, or opinions in news items) and (2) including any assertion or reference from the journalist (or other person), in which (s)he judges, or condemns what the individuals or groups in power say or do. In practice, the former is a statement and/or opinion in which a journalist (or non-journalist) questions the validity or truthfulness of what those individuals or groups in power say or do. The criticism is revealed in the form of quotes, statements and/or negative opinions.

Table 2

\section{Questioning and criticism in the news items}

\begin{tabular}{||l|c|c|c|c|c|c|}
\hline \hline \multicolumn{7}{||}{ Questioning: journalist's evaluation of the following types of an organization (\%) } \\
\hline & Political & Business & Civic & Transnational & More than one \\
\hline Gazeta Wyborcza & 12.5 & 4.7 & 2.6 & 0.0 & 0.3 \\
\hline Rzeczpospolita & 10.6 & 1.6 & 0.0 & 0.0 & 0.0 \\
\hline Fakt & 12.2 & 3.6 & 0.3 & 0.7 & 0.3 \\
\hline Nasz Dziennik & 23.0 & 0.4 & 0.4 & 1.3 & 0.0 \\
\hline TOTAL & $\mathbf{1 4 . 1}$ & $\mathbf{2 . 8}$ & $\mathbf{1 . 0}$ & $\mathbf{0 . 4}$ & $\mathbf{0 . 2}$ \\
\hline \multicolumn{7}{|c|}{ Questioning: other (\%) } \\
\hline Gazeta Wyborcza & 24.8 & 5.0 & 2.9 & 0.0 & 1.7 \\
\hline Rzeczpospolita & 23.5 & 1.2 & 0.0 & 0.4 & 0.4 \\
\hline Fakt & 5.0 & 2.0 & 0.7 & 1.3 & 0.0 \\
\hline Nasz Dziennik & 37.4 & 0.4 & 0.4 & 1.3 & 0.0 \\
\hline TOTAL & $\mathbf{2 1 . 8}$ & $\mathbf{2 . 4}$ & $\mathbf{1 . 1}$ & $\mathbf{0 . 6}$ & $\mathbf{0 . 6}$ \\
\hline \multicolumn{7}{|c|}{ Criticism: Journalist's evaluation (\%) } \\
\hline Gazeta Wyborcza & 8.5 & 2.3 & 1.7 & 0.0 & 0.3 \\
\hline Rzeczpospolita & 5.9 & 0.4 & 0.0 & 0.0 & 0.0 \\
\hline Fakt & 12.5 & 2.0 & 0.0 & 0.3 & 0.3 \\
\hline Nasz Dziennik & 22.6 & 0.4 & 1.3 & 1.7 & 0.0 \\
\hline TOTAL & $\mathbf{1 1 . 8}$ & $\mathbf{1 . 4}$ & $\mathbf{0 . 8}$ & $\mathbf{0 . 4}$ & $\mathbf{0 . 2}$ \\
\hline \multicolumn{7}{|c|}{ Criticism: other (\%) } \\
\hline Gazeta Wyborcza & 21.3 & 3.5 & 3.8 & 0.3 & 1.5 \\
\hline Rzeczpospolita & 27.1 & 0.8 & 0.4 & 0.4 & 0.4 \\
\hline Fakt & 7.6 & 2.0 & 0.7 & 1.7 & 0.0 \\
\hline Nasz Dziennik & 43.0 & 0.4 & 0.9 & 0.4 & 0.0 \\
\hline TOTAL & $\mathbf{2 3 . 3}$ & $\mathbf{1 . 9}$ & $\mathbf{1 . 6}$ & $\mathbf{0 . 7}$ & $\mathbf{0 . 5}$ \\
\hline \hline
\end{tabular}

Journalistic Role Performance Around the Globe. 
Table 3 presents data on a frequency of the news items including an assertion or reference from the journalist (or the other), in which he/she accuses or makes evident something hidden, not only illegal, but also irregular or inconvenient concerning individuals or groups of power, for example, cases of poor administration, corruption, fraud, harassment, political blockade to legal initiatives, misinformation, or political scandals, among others.

Table 3

Denouncement in news items

\begin{tabular}{|c|c|c|c|c|c|}
\hline \multicolumn{6}{|c|}{$\begin{array}{c}\text { Denouncement: Journalist's evaluation of following type } \\
\text { of an organization }(\%)\end{array}$} \\
\hline & Politics & Business & Civil & $\begin{array}{l}\text { Transnational } \\
\text { organizations }\end{array}$ & \begin{tabular}{c|} 
More than \\
one
\end{tabular} \\
\hline Gazeta Wyborcza & 2.0 & 0.9 & 0.9 & 0.0 & 0.0 \\
\hline Rzeczpospolita & 11.0 & 0.8 & 0.0 & 0.0 & 0.0 \\
\hline Fakt & 3.6 & 1.3 & 0.3 & 0.3 & 0.0 \\
\hline Nasz Dziennik & 4.3 & 0.4 & 0.4 & 0.4 & 0.4 \\
\hline TOTAL & 5.0 & 0.9 & 0.4 & 0.2 & 0.0 \\
\hline \multicolumn{6}{|c|}{ Denouncement: other (\%) } \\
\hline Gazeta Wyborcza & 5.0 & 1.2 & 0.6 & 0.0 & 0.0 \\
\hline Rzeczpospolita & 3.9 & 0.4 & 0.0 & 0.0 & 0.0 \\
\hline Fakt & 2.0 & 1.0 & 0.3 & 0.7 & 0.3 \\
\hline Nasz Dziennik & 3,9 & 0.0 & 0.0 & 0.0 & 0.0 \\
\hline TOTAL & 3.7 & 0.8 & 0.3 & 0.2 & 0.1 \\
\hline
\end{tabular}

Journalistic Role Performance Around the Globe.

Finally, Table 4 presents the data on the frequency of four more indicators of the watchdog model: (1) external investigation (investigations that were not carried out by the journalist - such as judicial, administrative, specialized/academic research, among others - but which the journalist covers extensively), (2) confrontation between the journalist and one or more of those in power, (3) investigative reporting (items informing on any abuse of power or a wrongdoing, and so on, based on extensive inquiry and research, i.e. independent review of legal documents, public records, or direct observation, beyond reliance on leaks and secondary sources of information, and (4) information on judicial or administrative processes against individuals or groups of power. 
Table 4

Presence of the watchdog model (\% of items including following indicators)

\begin{tabular}{||l|c|c|c|c|c||}
\hline \hline & $\begin{array}{c}\text { Gazeta } \\
\text { Wyborcza }\end{array}$ & Rzeczpospolita & Fakt & $\begin{array}{c}\text { Nasz } \\
\text { Dziennik }\end{array}$ & Total \\
\hline External investigation & 4.2 & 14.1 & 20.5 & 13.0 & 12.7 \\
\hline Conflict & 0.3 & 0.8 & 0.3 & 1.7 & 0.7 \\
\hline Investigative reporting & 4.7 & 4.3 & 3.0 & 4.8 & 4.2 \\
\hline Information on processes & 10.2 & 14.5 & 2.6 & 9.1 & 8.9 \\
\hline
\end{tabular}

Journalistic Role Performance Around the Globe.

The findings presented in Tables 2-4 reveal that the watchdog role is commonly used by both the high quality press and the tabloid. It is worth mentioning, however, that the number of items focused on questioning or criticizing individuals or groups with political power by other actors is higher than a number of the items in which journalists question or criticize politicians or political parties. In total, 14 per cent of the items included a quote, statement and/or opinion given by a journalist, while almost 22 per cent of the items have an example of such an expression given by someone other than the journalist. This proportion is similar in the case of items including any critical comment (11.8 per cent and 23.3 per cent, respectively).

In other words, journalists more often let others (politicians, experts, or citizens) question the validity or truthfulness of what the individuals or groups in power say or do and present negative evaluations of political actors' statements or performances. The only exception is the tabloid Fakt, in which journalists more frequently than non-journalists present their doubts and opinions of political actors.

However, it was Nasz Dziennik that included the highest number of news items providing assertions or references in which they questioned or judged political actors' activities. Almost one quarter of all the items published in that daily newspaper included negative opinions expressed directly by journalists, while in around 40 per cent of the items others expressed their skepticism or condemnation. It is the newspaper's political orientation (right-wing) and negative attitude toward the government of Platforma Obywatelska and Polskie Stronnictwo Ludowe (Civic Platform and Polish People's Party) that influenced the content of the news items. Nasz Dziennik has been openly supporting Prawo i Sprawiedliwość (Law and Justice) and other non-liberal, right-wing political parties that were in opposition to the government at the time of the study (2012-2013). 
The watchdog role is played by Polish journalists only in regard to political actors, while it is almost absent in regard to any other elites or groups (business, civic organizations, or transnational organizations). No more than 3 per cent of the news items in total included any negative opinion or evaluation of the business elite, and even less of any other type of organizations or companies.

Although Polish journalists seem to be interested in covering judicial or administrative processes (around 10 per cent of the news items in total) or external investigations (around 13 per cent), they are less eager to conduct inquiry and research on their own (around 4 per cent of all the news items covered a description or results of the independent review of legal documents, public record, or direct observation). Also, less than 10 per cent of the stories included a denouncement. Journalists from the tabloid Fakt most frequently focused on investigations that were not carried out by journalists: 20.5 per cent of the news items were devoted to the external investigations on wrongdoings. Cases of conflict or confrontation between a journalist and one or more of those in power were very rare.

\section{Loyal-facilitator model}

The loyal-facilitator type of journalist is revealed in two manners. In its first variant, journalists support the political agenda set by the government, show loyalty to power, support and defend the government's policies, and often become public relations channels for the transmission of government messages to the public. In practice, journalists praise, promote or defend specific official activities or measurements of improvement carried out by the political or economic powers, favorably stress and highlight leadership or management skills, as well as the personal characteristics of political leaders, or use positive adjectives when referring to these actors. In the second type of this model, journalists emphasize their own country's progress in any relevant dimension or field, or advances and triumphs in comparison to other countries in the world. In that case, news items highlight individuals or groups who have triumphed in the country or abroad explicitly within the news item, refer to activities organized with the objective of promoting the country's image, or include statements that positively value being from a specific nation.

Table 5 shows the data on the presence of the attributes of that type of journalism. The numbers clearly show that Polish journalists, regardless of their political orientation or the type of the media organization they are working for, do not identify with the loyal-facilitator model. 
Presence of the loyal-facilitator model

Table 5 (\% of items including following indicators)

\begin{tabular}{|l|c|c|c|c|c|}
\hline & $\begin{array}{c}\text { Gazeta } \\
\text { Wyborcza }\end{array}$ & Rzeczpospolita & Fakt & $\begin{array}{c}\text { Nasz } \\
\text { Dziennik }\end{array}$ & Total \\
\hline Defense/support activities & 4.1 & 1.2 & 1.0 & 2.6 & 2.3 \\
\hline Defense/support policy & 2.3 & 0.0 & 1.3 & 1.7 & 1.4 \\
\hline Positive image - political elite & 0.6 & 2.0 & 0.3 & 0.4 & 0.8 \\
\hline Positive image - economic elite & 0.9 & 1.2 & 1.3 & 0.0 & 0.9 \\
\hline $\begin{array}{l}\text { Comparison to the rest of the } \\
\text { world }\end{array}$ & 5.8 & 4.7 & 3.3 & 3.5 & 4.4 \\
\hline Progress/ success & 3.2 & 4.7 & 0.7 & 3.5 & 2.7 \\
\hline National triumph & 5.8 & 4.7 & 3.3 & 3.5 & 4.4 \\
\hline Country image & 1.7 & 1.6 & 1.0 & 1.3 & 1.4 \\
\hline Patriotism & 0.9 & 0.8 & 0.0 & 1.3 & 0.7 \\
\hline
\end{tabular}

Journalistic Role Performance Around the Globe.

Service journalism model

The data presented in Table 6 shows that none of the selected newspapers provide a significant number of tips and advice in their news items. Rzeczpospolita and Gazeta Wyborcza, however, pay some attention to the consequences or meaning that certain facts or events have for people's everyday personal lives. In Rzeczpospolita around 30 per cent of the news items focused on that aspect of a story.

Table 6

Presence of the service journalism model (\% of items including following indicators)

\begin{tabular}{|l|c|c|c|c|c||}
\hline \hline & $\begin{array}{c}\text { Gazeta } \\
\text { Wyborcza }\end{array}$ & Rzeczpospolita & Fakt & $\begin{array}{c}\text { Nasz } \\
\text { Dziennik }\end{array}$ & Total \\
\hline Impact on everyday life & 18.1 & 30.6 & 9.2 & 1.7 & 15.2 \\
\hline Tips/advice: grievance & 12.2 & 7.1 & 2.3 & 1.3 & 6.2 \\
\hline Tips/advice: risk & 6.4 & 7.2 & 5.0 & 1.3 & 5.2 \\
\hline Consumer advice & 5.0 & 4.3 & 1.0 & 0.0 & 2.7 \\
\hline
\end{tabular}

Journalistic Role Performance Around the Globe.

Infotainment model

Not surprisingly, the tabloid Fakt was the newspaper with the highest frequency of the infotainment model indicators (see Table 7). All the attributes of that dimension, apart from morbid images, were present in at 
least 15 per cent of news items. Almost one third of the news items centered on one or more persons and their intellectual, mental, physical or social characteristics or personal background. In practice, these news items included details on profession, age, name, marital status, and so on.

Table 7

Presence of the infotainment model (\% of items including following indicators)

\begin{tabular}{||l|c|c|c|c|c||}
\hline \hline & $\begin{array}{c}\text { Gazeta } \\
\text { Wyborcza }\end{array}$ & Rzeczpospolita & Fakt & $\begin{array}{c}\text { Nasz } \\
\text { Dziennik }\end{array}$ & Total \\
\hline Personalization & 10.2 & 12.5 & 31.0 & 4.8 & 15.2 \\
\hline Private life & 2.3 & 2.4 & 15.2 & 2.6 & 5.8 \\
\hline Sensationalization & 4.1 & 2.7 & 26.4 & 1.7 & 9.3 \\
\hline Scandal & 9.9 & 9.4 & 20.1 & 2.2 & 11.0 \\
\hline Emotions: description & 8.7 & 7.5 & 20.8 & 4.3 & 10.8 \\
\hline Emotions: images & 3.8 & 0.8 & 17.5 & 2.6 & 3.0 \\
\hline Morbid: description & 1.7 & 3.1 & 20.5 & 3.5 & 7.4 \\
\hline Morbid: image & 0.9 & 0.8 & 5.3 & 0.4 & 1.9 \\
\hline
\end{tabular}

\section{Journalistic Role Performance Around the Globe.}

Nevertheless, the quality press also provides such information in news items: personalization was an attribute of 10 and 12 per cent of news items published in Gazeta Wyborcza and Rzeczpospolita, respectively. Around 10 per cent of the news items under the study covered a story labeled by the quality press journalists as a scandal. In a similar amount of news stories, the journalists of Gazeta Wyborcza and Rzeczpospolita made explicit references to feelings or emotions ( 8.7 and 7.5 per cent, respectively). On the contrary, Nasz Dziennik seems to be the most resistant to the trend of tabloidization.

Civic oriented journalism

The indicators of the civic model were included most frequently in Nasz Dziennik. In one third of the news items in the study, journalists presented the citizens' perspective, while around 20 per cent of the news items included information on citizens' acts such as campaigns, collective actions, protests, commemorations, demonstrations and protests. Furthermore, around 20 per cent of items included regular or organized citizens' demands or proposals on how different political decisions should be handled. And, most importantly, one quarter of the news items were in favor of what citizens perceived, denounced, or demanded. 
Table 8

Presence of the civic model (\% of items including following indicators)

\begin{tabular}{||l|c|c|c|c|c|}
\hline \hline & $\begin{array}{c}\text { Gazeta } \\
\text { Wyborcza }\end{array}$ & Rzeczpospolita & Fakt & $\begin{array}{c}\text { Nasz } \\
\text { Dziennik }\end{array}$ & Total \\
\hline Citizens' perspective & 17.5 & 14.9 & 6.6 & 34.4 & 17.4 \\
\hline Citizens' demand & 8.7 & 3.9 & 2.3 & 19.1 & 8.0 \\
\hline Credibility & 11.4 & 1.6 & 4.0 & 23.0 & 9.5 \\
\hline Local impact & 5.5 & 7.1 & 3.0 & 7.4 & 5.6 \\
\hline Education & 7.0 & 3.5 & 0.7 & 3.5 & 3.8 \\
\hline Background information & 1.5 & 14.5 & 0.3 & 2.6 & 4.3 \\
\hline Citizens' questions & 0.3 & 0.0 & 0.7 & 1.3 & 0.5 \\
\hline Citizens' activities & 6.1 & 5.9 & 1.0 & 18.7 & 7.3 \\
\hline Support for activities & 0.3 & 1.2 & 0.3 & 7.4 & 1.9 \\
\hline
\end{tabular}

Journalistic Role Performance Around the Globe.

It is worth mentioning that Nasz Dziennik was at that time extensively covering the demonstrations under the slogan "In defense of Television Trwam". Over the two years 2012-2013 (the period of data collection) there were 175 marches and protests in many Polish cities and abroad. They were organized to protest against a decision made by the National Broadcasting Council not to provide a license for broadcasting in the first nationwide multiplex (terrestrial digital broadcasting) to Telewizja Trwam. Telewizja Trwam is a Catholic TV channel founded in 2003 and located in Torun. It belongs to the Lux Veritatis Foundation. The station is owned by the Warsaw Province of the Congregation of the Most Holy Redeemer, the same congregation that Rev. Tadeusz Rydzyk (the founder of Nasz Dziennik) belongs to.

\section{Conclusions}

The findings indicate that the watchdog model is the most commonly used model in the Polish press, followed by the infotainment and civic models. However, the findings of the content analysis primarily support the observation on the political orientations of the Polish newspapers and political parallelism of the Polish media system: the anti-(PO/PSL) governmental journalists working for Nasz Dziennik most eagerly played the role of a watchdog and most extensively covered anti-governmental civic activities at that time. Hence, in order to understand the data, one needs to consider the political context. If the study were to be conducted in late 
2015 and early 2016, one could expect Gazeta Wyborcza to be the leader in covering civic activities and the protests organized by Komitet Obrony Demokracji [Democracy Defense Committee] against the new government of Prawo i Sprawiedliwość.

The other clear pattern can be seen in the case of the tabloid Fakt, that included much more frequently the infotainment model indicators than any other newspaper in the study. The findings showed that journalists working for Fakt are also interested in monitoring political actors, but they are more focused on the processes and investigations than the political agenda. Hence, one may argue that it is the scandal aspect of a political story that attracts tabloid journalists' attention. Nevertheless, the quality press also seems prone to the infotainment model of journalism.

\section{References}

Culbertson H. (1983), Three perspectives in American journalism, "Journalism Monographs", no. 83, pp. 1-33.

Dobek-Ostrowska B., Barczyszyn P., Michel A. (2013), Zmiana w dziennikarstwie. Kultura zawodowa polskich dziennikarzy (badania ilościowe), „Studia Medioznawcze", no. 1, pp. 11-28.

Donsbach W. (2008), Factors Behind Journalists' Professional Behavior: A Psychological Approach to Journalism Research, in: Global Journalism Research, eds. M. Löffelholz, D. Weaver, Blackwell Publishing, Malden-Oxford-Carlton, pp. 65-78.

Donsbach W., Patterson T. E. (2004), Political news journalists: partisanship, professionalization, and political roles in five countries, in: Comparing Political Communication. Theories, Cases, and Challenges, eds. F. Esser, B. Pfetsch, Cambridge University Press, Cambridge, pp. 251-270.

Głowacki M. (2013), Dziennikarze polscy w świetle studiów porównawczych systemów odpowiedzialności mediów w Europie, „Studia Medioznawcze”, no. 1(52), pp. 29-44.

Hanitzsch T. (2007), Deconstructing Journalism Culture. Toward a Universal Theory, "Communication Theory", no. 17(4), pp. 367-385.

Mellado C. (2014), Professional roles in news content: Six dimensions of journalistic role performance, "Journalism Studies", DOI:10.1080/1461670X.2014.922276.

Mellado C., Lagos C. (2014), Professional Roles in News Content: Analyzing Journalistic Performance in the Chilean National Press, "International Journal of Communication", no. 8, pp. 2090-2112.

Olędzki J. (1998), Polish Journalists: Professionals Or Not?, "The Global Journalist. News People around the World", ed. D.H. Weaver, Hampton Press, Inc., New Jersey, pp. 257-276. 
Stępińska A., Ossowski Sz., Pokrzycka L., Nowak J. (2012), The Journalists and Journalism of Poland, in: The Global Journalist in the $21^{\text {st }}$ Century, eds. D. H. Weaver, L. Willnat, Routledge, New York-London, pp. 255-266.

Weaver D. H. (ed.) (1998), The Global Journalist. News People Around the World, Hampton Press Inc., Cresskill-New Jersey.

Weaver D. H., Wilhoit G. C. (1996), The American Journalist in the 1990s: U.S. News People at the End of an Era, Lawrence Erlbaum Asssociaties, Mahwah, NJ.

Weaver D. H., Willnat L. (eds.), (2012), The Global Journalist in the 21st Century: News People around the World, Routledge, New York.

Wirtualne Media (2014), ,, Gazeta Polska Codziennie” i „,Gazeta Wyborcza” ostro w dół. „Dziennik Gazeta Prawna” przed „Rz”, retrieved from: http://www. wirtualnemedia.pl/artykul/gazeta-polska-codziennie-i-gazeta-wyborcza-ostro-w-dol-dziennik-gazeta-prawna-przed-rz\#. 
